\title{
Bodrum'da Kafeslerde Balık Yetiştiriciliğinin Fitoplanktona Etkisi
}

\author{
Nilsun DEMIR ${ }^{1}$
}

Doğan ATAY'

\author{
Geliș Tarihi : 15.09,1999
}

\begin{abstract}
Ozet : Kafeslerde çipura ve levrek balığı yetiştiriciliğinin ritoplanktona etkisinin belirlenmesi amaciyla kafesler civarında ve açıkta (kontrol) iki istasyon seçilmiştir. Fitoplanikton sayısi, kafes istasyonunda açıkta seçilen istasyondan yöksek bulunmuştur $(p<0,01)$. Kafes istasyonunun kjorofil a degerleri de açıkta seçilen istasyondakinden yöksektir. Pennat diatomiar, Rhizosolenia spp., Thalassionema nitzschioides ve Leptocylindricus danicus türleriyle dominant olarak bulunmuşlardır. Fitoplaniton kompozisyonu açısından kafes istasyonu ve açıkta seçilen istasyon arasinda bariz bir farklulik góruimemiştir.
\end{abstract}

Anahtar Kelimeler: Fitoplankton, kafes yetiștiriciliği, klorofil, pennat diatom

\section{Impact of Fish Cage Culture on the Phytoplankton in Bodrum}

\begin{abstract}
The phytoplankton were monitored in two stations (near cages and open water) of a cage farm to determine the impact of cage culture of sea bream and bass. Phytoplankton numbers were higher in cage station than in open station $(p<0,01)$. Chlorophyil a values of cage station were higher than open station too. Pennale diatoms were dominated by Rhizosolenia spp., Thalassionema nitzschioides and Leptocylindricus danicus. Phytoplankton composition seems to be not different in cage and open stations.
\end{abstract}

Key Words : Phytoplankton, cage culture, chiorophyll, pennate diatom

\section{Giriş}

Olkemizde kafeslerde balık yetiştiriciliği son yıllarda önemli dazeyde gelişme göstermiştir. Güney Ege'de kafeslerde çipura ve levrek yetiştiriciliği yapan ișletme sayısı 1984 yilinda 2 iken, 1995 yilinda 124'e ulaşmıştır (Işgören 1995, Kürüm 1996).

Kafeslerde balık yetiștiriciliğinde, kullanilan balık yemleri ve atiklarından kaynaklanan bir ötrofikasyon olduğu bildirilmektedir (Folke ve Kautsky 1989). Bu ötrofikasyon fitoplankton tür kompozisyanunda bir değişmeye de neden olabilir (Pillay 1992). Bir kafes işletmesinin çevreye en önemli etkisi su ve sedimentte fosfor, azot ve organik madde yükünü artirmasıdir. Salmonid aretimi yapilan kafeslerde fosfor yükü ve klorofil konsantrasyonu arasındaki ilişski incelenmiş ve bir gölun su kalitesini kabul edilebilir sınırlar içerisinde tutarak balık üretim kapasitesini tahmin etmeye younelik bir model geliștirilmiştir (Beveridge 1984). Iskoçya'da bir gölde kafeslerde balik yetiştiriciliğinin fitoplankton ve perifiton üzerine etkileri incelenmiş ve fitoplanktonun kafes yakınında seçilen istasyonda gölde seçilen diğer istasyona (kontrol) góre sayıca önemli bir artıई gösterdiği belirtilmiștir (Stirling ve Dey 1990).

Kafesierde balik yetiştiriciligi açısından fitoplanktonun önemli bir yönū de fitoplankton patlamalarıdır ve Batı Kanada, Sili, Norvec ve Iskoçya'da önemli duzeyde balik olomlerine neden oldukları bildirilmektedir. 1998 yilinda Bati Iskoçya'da bir fitoplankton patlamasında 13 ton Salmon balığı ölmüştür (Treașurer ve ark. 1999), Iskandinavya'da 35 salmonid işletmesinin toksik bir alg patlamasindan etkilendiği bildirilmiştir (Folke ve Kautsky 1989), Balık çiftliklerinin yönetim stratejilerinde toksik turlerin tanımlanması jçin rutin mikroskobik analizler bulunmalıdır. Bu tip bir izleme programı alg patlamaları görolduğunde, yemlemenin kesilmesi, kafeslerin başka bir alana taşinması veya hasatın yapılması gibi onlemierin alınması için gereklidir (Pullin 1993).

Yoğun alg topluluklarının gece oksijeni tüketmeieri ani balık ollumlerine neden olmaktadır. Salmonid yetiștiriciliğinde, Chastoceros sp.'nin 5 adet/mi gibi bir artışında bile balıklarda solungaç hasarlarına neden olduğu ve hastatıklara yakalanma riskini artırdığı belirtilmiştir (Steward 1997).

Ülkemizde de lzmir körfezinde (Koray ve ark. 1992) ve Urla yöresinde (Cirik ve ark. 1991) 'red-tide' olaylarının da dahil olduğu alg patlamaları gorolmektedir. Bodrum ve civarının fitoplanktonunda Dinoflagellatların dominant olduğu bildirilmiştir (Gökalp 1972).

Kafeslerde balık yetiştiriciliğinin ekosistem uzerine etkileri Trabzon sahil şeridinde incelenmiştir (Dũzgûneş ve ark. 1995). Kafeslerde balık yetiştiriciliği çevreyi direkt olarak etkilerken, çevresel koşullardaki değişmelerde kafes yetiştiriciliğini etkiler. lyi bir işletme, çevresel koşullarinda monitör ve indikatörüdôr. Bu araştırmada, Bodrum yöresinde kafeslerde balık yetiştiriciliği yapılan bir koyda fitoplankton kompozisyonunun değişiminin tesbiti amaçlanmıştir. Bu araștırmanın kafeslerde balık yetiştiriciliğinin çevreye etkilerinin incelenmesinde temel oluşturacağı kanisindayız.

\footnotetext{
Bu araștırma DPT ve ASAUM tarafından desteklenen projenin bir bölumudur.

'Ankara Üniv. Ziraat Fak. Su Ürünleri Bölümü-Ankara
} 


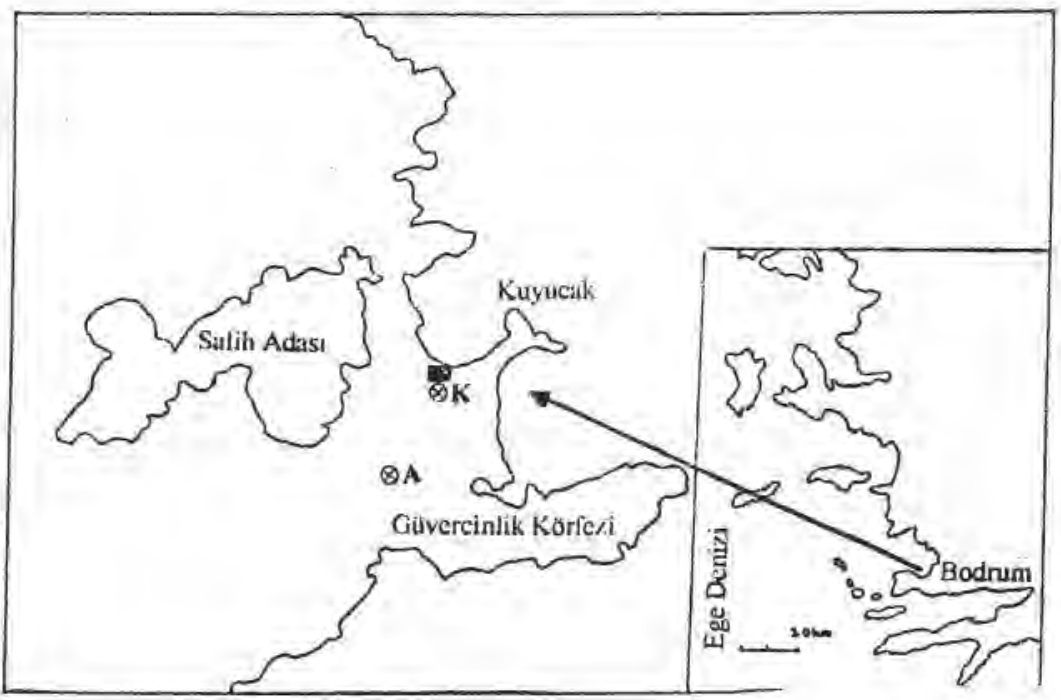

Şekil 1. Araștırma alanının haritası ve örnek alınan istasyonlar ( $K$ : Kafes istasyonu, A Açıkta seçilen kontrol istasyonu)

\section{Materyal ve Yöntem}

Bu araștırmada Ocak-Ekim 1997 tarihleri arasında sürdürülmüş, örnekler ocak, nisan, temmuz ve ekim aylarında alınmıştır.

Araştırma, Bodrum'a 20 km. Aydin ili Milas ilçesine $25 \mathrm{~km}$ uzaklıkta olan Kuyucak koyunda ozel bir ișletmede yürütolmüştür (Şekil 1).

Tesiste $5 \times 5 \times 5 \mathrm{~m}$ boyutlarındaki ahşap çerçeveli ağ kafeslerde yılda 500 ton çipura ve levrek balığı aretilmektedir. Su örnekleri, kafeslerin arasında seçilen $\mathrm{K}$ istasyonu ve tesisten $300 \mathrm{~m}$ uzakta seçilen A istasyonundan yüzeyin $20 \mathrm{~cm}$ altindan Ruttner su alıcısı ile alınmıştır. A istasyonu Kuyucak koyundan uzakta ve tesisten etkilenmeyecek bir konumdadır.

Fitoplankton sayımında, $500-1000$ ml'lik su örnekleri sonuç derişimi $\% 4$ olacak şekilde formaldehit çözeltisi ile tesbit edilmiş, sayım hücrelerinde çöktürülerek inverted mikroskop yardımıyla sayılmıştır. Koloni ve filamentler tek bir organizma olarak sayilmıştır (APHA 1975). Fitoplanktonun teşhisinde, Pankow (1976), Taylor (1976), Cupp (1977) ve Sournia (1986)'ya ait kaynaklar kullanılmıştır. Klorofil $a$ analizinde, 1000 ml'lik su örnekleri Whatman GFIC süzgeç kağıdından süzöimús, \% 90'lik asetonla ekstrakte edilmiş ve ekstraktın optik yoğunluğu spektrofotometrede 665,645 ve $630 \mathrm{~nm}$ dalga boylarinda okunarak düzeltme katsayılarına göre klorofil a hesaplanmıștir (Strickland ve Parsons 1972). Verilerin istatistiksel olarak değerlendirilmesinde Statistica ve Minitab paket programları kullanılmıştır.

\section{Sonuç ve Tartışma}

Araștırma suresince $K$ ve $A$ istasyonlanindan alinan su örneklerinde fitoplankton sayısının değişimi Çizelge 1 'de verilmiştir. Fitoplankton sayisi; ocak, nisan, temmuz ve ekim aylarında $K$ istasyonunda $A$ istasyonuna göre yüksek bulunmuştur. İstasyonlar arası farklılik ANOVA testi ile incelenmiş ve varyans çözümleme tablosunda görülebileceği gibi istatistiksel olarak önemli bulunmuştur $(p<0,01)$ (Çizelge 2). Fitoplankton sayısının $K$ ve $A$ istasyonlarında aylara göre değişimi Duncan testi ile incelenmiş; ocak, nisan, temmuz aylarında önemli, ekim ayında ise ônemsiz olduğu bulunmuştur (Çizelge 1). Fitoplankton sayısının en yüksek değeri, temmuz ayında $\mathrm{K}$ Istasyonunda ortalama 545 adet/ml olarak tesbit edilmiştir. Bu değer aynı ayda $\mathrm{A}$ istasyonundakinden yaklaşık ôç kat daha yüksektir. Stirling ve Dey (1990), fitoplankton sayısını kafeslerin yakınında, uzakta seçilen istasyona göre daha yăksek olduğunu ve bu durumun kafesler nedeniyle besin maddesi artışından kaynaklandığını bildirmişlerdir. Araștırmamızda fitoplankton sayısının $K$ istasyonunda daha yüksek oluşunda kafeslerde balık yetiştiriciliği yanısıra, $\mathrm{K}$ istasyonunun bir koy içerisinde yer alışı ve su yenilenmesinin daha az olabileceği veya $A$ istasyonunda akıntıların daha etkili olabileceği gibi faktörler göz ardı edilmemelidir.

Araștırma suresince, 11'i Dinophyceae'ye ve $14^{\prime} 0$ Bacillariophyceae'ye ait olmak uzere toplam 25 tar teşhis edilmiştir (Çizelge 3). Gökalp (1972), Bodrum körfezinde haziran ve temmuz aylarında Dinophyceae'ye ait 12 ve Bacillariophyceae'ye ait 6 tör teşhis ettiğini bildirmiştir.

Çizelge 1. K ve A istasyonlarında fitoplankton sayısının aylara göre değişimi (OrtalamaıStandart hala) (adet/mi)

\begin{tabular}{|c|c|c|c|c|}
\hline Istasyon & ocak & nisan & temmuz & ekim \\
\hline K & $18,3^{2} \pm 0,45$ & $42,1^{\mathrm{x}} \pm 1,26$ & $545,0^{2} \pm 8,12$ & $27,5^{\mathrm{B}} \pm 1,71$ \\
\hline $\mathrm{A}$ & $2,4^{\mathrm{b}} \pm 0,08$ & $24,5^{\mathrm{b}} \pm 1,34$ & $174,1^{\mathrm{b}} \pm 1,52$ & $14,3^{\mathrm{B}} \pm 2,02$ \\
\hline
\end{tabular}

2.t. Ayni sütunda farklı usıu hart taşıyan ortalamalar arasındaki farkłılık istatistiksel alarak önemlidir $(p<0,05)$ 
Çizelge 2. Fitoplankton sayısı için varyans çözümlemesi

\begin{tabular}{|l|c|c|c|c|}
\hline Varyasyon kaynağı & S.D. & Kareler toplami & F & P \\
\hline Gruplar arası & 3 & 1147687 & 3021,7 & 0,01 \\
\hline Ozellikler arası & 1 & 43293 & 1139,9 & 0,01 \\
\hline AyxGrup & 3 & 31657 & 833,5 & 0,01 \\
\hline
\end{tabular}

Çizeige 3. $\mathrm{K}$ ve $\mathrm{A}$ istasyoniarında fitoplankton torleri listesi (+++ \%60-100 oraninda mevcut, ++; \%20-60 oranında mevcut, $+; \% 20$ 'den az)

\begin{tabular}{|l|c|c|}
\hline Dinophyceae & $\mathbf{K}$ & $\mathbf{A}$ \\
\hline Ceratium contortum (Gourr.) Cleve & + & + \\
\hline Ceratium furca (Ehr.) Clap.\&Lachm. & ++ & ++ \\
\hline Ceratium fusus (Ehr.) Duj. & ++ & ++ \\
\hline Ceratium macroceros (Ehr.) Vanhöff & ++ & ++ \\
\hline Ceratium trichoceros (Ehr.) Kof. & - & + \\
\hline Ceratium tripos (O.F.Mull.) Nitzsch & ++ & ++ \\
\hline Dinophysis caudata Kent-Sav. & + & + \\
\hline Gymnodinium herbaceum Kof. & ++ & ++ \\
\hline Oxytoxum Scolopax Stein & + & + \\
\hline Prorocentrum micans Ehr. & ++ & ++ \\
\hline Protoperidinium divergens(Ehr.)Balech & ++ & ++ \\
\hline Bacillariophyceae & & \\
\hline Bacillaria paradoxa Gmelin & + & + \\
\hline Chaetoceros affinis Lauder & ++ & ++ \\
\hline Chaetoceros brevis Schütt & +++ & ++ \\
\hline Chaetoceros decipiens Cleve & +++ & +++ \\
\hline Leptocylindricus danicus Cleve & ++ & +++ \\
\hline Licmophora abbreviata Agardh & + & + \\
\hline Nitzschia longissima Ralfs & + & + \\
\hline Pleurosigma elongatum W. Smith & + & + \\
\hline Rhizosolenia alata Bright & + & ++ \\
\hline Rhizosolenia calcar-avis Schultze & +++ & +++ \\
\hline Rhizosolenia styliformis Bright. & ++ & ++ \\
\hline Striatella unipunctata (Lyng.) Ag. & +++ & +++ \\
\hline Thalassionema nitzschioides Grun. & +++ & ++ \\
\hline Thalassiothrix frauenfeldii Grun. & - & + \\
\hline
\end{tabular}

A

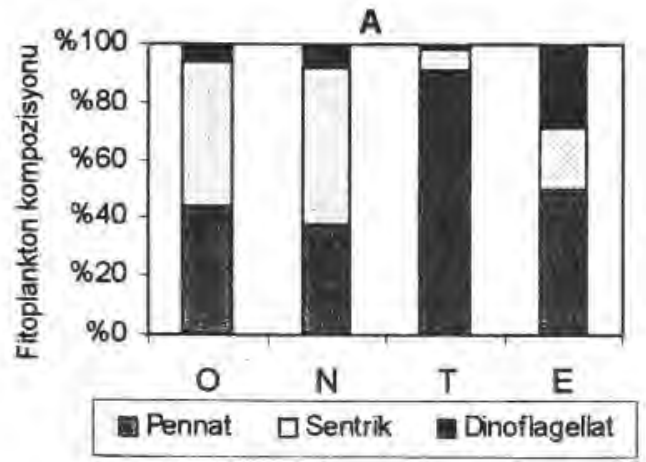

Araştirma süresince fitoplankton kompozisyonunun aylara göre değişimi incelendiğinde, açıkta seçilen istasyonda nisan ayı dışında pennat diatomların diğer gruplara oranla daha yöksek sayıda bulunduğu görülmektedir (Şekil 2). Fitoplankton kompozisyonu açısından, $K$ ve $A$ istasyonları arasinda onemli bir farklılığa rastlanmamıştır. Ocak örneklerinde, pennat diatomlardan Rhizosolenia spp., Thalassionema nitzschioides hakim durumda iken, sentrik diatomlardan da Chaetoceros spp. ve dinoflagellatlardan Ceratium spp.'nin bulunduğu belirlenmiş, nisan orneklerinde pennat ve sentrik diatomların hakimiyeti devam etmiş ve temmuz örneklerinde pennat diatomlar Rhizosolenia spp., Thalassionema sp. ve Leplocylindricus danicus ile fitoplanktonda önemli bir artışa neden olmuşlardır. Ekim ayında sentrik diatomlar ve dinoflagellat oraninda bir artış görülse de fitoplankton sayıca azalmıştır. Ilıman bölgede bulunan kıyısal sularda kış ve bahar aylarında Chaetoceros artışları olduğu bildirilmiştir (Nakahara 1978). Batı Avrupa denizlerinde Rhizosolenia spp., Leptocylindricus sp. ve Thalassionema sp.'nın bahar ve yaz artışları gösterdiği belirtilmiştir (Boney 1989).

Araștırma sŭresince klorofil a, $0,75-6,73 \mathrm{mg} / \mathrm{m}^{3}$ arasında değişmiştir (Şekil 3). Klorofil $a, K$ istasyonunda $A$ istasyonuna gore daha yoksek bulunmuş ve en yüksek değeri de temmuz ayinda $K$ istasyonunda ölçülmūş, klorofil a'daki değişimler fitoplankton sayısına benzer bir değişim göstermiștir.

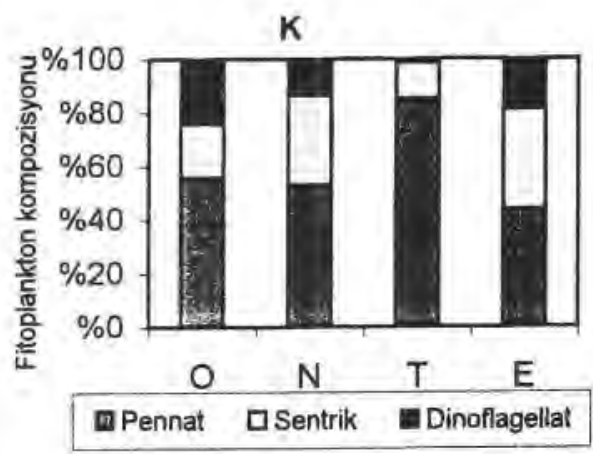

Şekil 2. Fitoplankton kompozisyonunun $A$ ve $K$ istasyonlarında ocak (O), nisan (N), temmuz (T) ve ekim (E) aylarında deḡişimi 


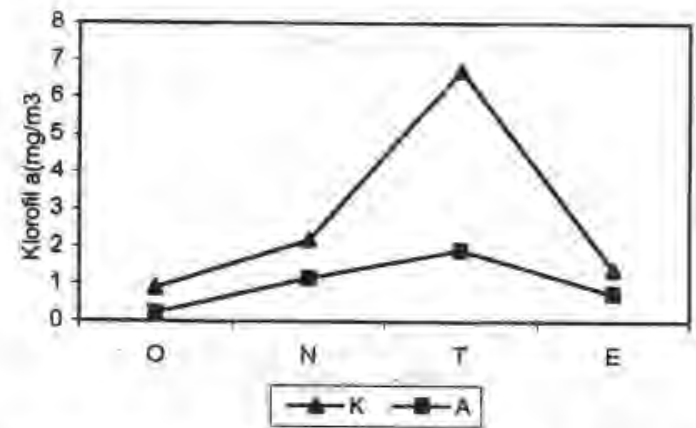

Şekil 3. Korofil a hın K ve A istasyonlarında ocak, nisan, temmuz ve ekim aylarında değişimi

Bodrum'da DEÜ tarafından ATAK Projesi kapsamında gerçekleştirilen çalışmalarda 1993 yılının kiș. ilkbahar ve yaz aylarında klorofil a'nın sırasıyla 0,09, 0,41 ve $0,81 \mathrm{mg} / \mathrm{m}^{3}$ olarak ölçuldăgo belirtilmiştir (Anonim 1998). Trabzon sahilinde kafeslerde balik yetiştiriciliğinin ekosistem azerine etkilerinin incelendiği araştırmada ise klorofil a'nin en yüksek değerinin $2,04 \mathrm{mg} / \mathrm{m}^{3}$ olarak kafesler yakınında değil şehir atıklarından etkilenen istasyonda bulunduğu belirtilmiştir (Düzgûneş ve ark. 1995). Araştırmamizda $K$ istasyonunda ölçalen klorofil a'nın oldukça yoksek oluşunun kafeslerde balık yetiştiriciliğinden kaynaklanabileceği sonucuna varılmıştır. Ancak fitoplankton sayisında olduğu gibi $K$ ve $A$ istasyonlarının konumlarındaki farklilık góz önünde bulundurulmalıdir.

Araştırma süresince, plankton patlamaları veya toksik etki oluşturan fitoplanktonlara rastlanmamiştır. Plankton patlamaları kısa súrelerde oluşabileceğinden daha sık örnek alma aralığı olan araștırmalar yapıımalıdırBodrum koşullarında 500 ton/yıl kapasitede kafes yetiştiriciliği fitoplankton kompozisyonunu önemli derecede değiştirmemiştir. Ancak mümkün olabilecek toksik patlamalar (toksik fitoplanktonların ani artışları) için fitoplanktonun ve su kalitesinin izlenmesi inmal edilmemelidir.

\section{Kaynaklar}

Anonim, 1998. Türkiye'nin Çevre Sorunlari'99. Turkiye Çevre Vakfı Yayini, Ankara, s. 464.

APHA, 1975. Standard Methods for the Examination of Water and Wastewater. $14^{\text {th }}$ Ed. John D. Lucas Co., USA, $1193 \mathrm{p}$.

Beveridge, M. C. M. 1984. Cage and pen fish farming. Carrying capacity models and environmental impact. FAO Fish. Tech. Pap. 225, p. 133.

Boney, A. D. 1989. Phytoplankton. $2^{\text {nd }}$ Ed. Edward Arnold Publ., London, p. 117.

Cirik, S., S.. Gökpınar, M. Önen ve O. Yaramaz, 1991. Urla iskelesi açıklarında deniz kirliliğinin neden olduğu bazı biyolojik olaylar. E. Ü. Su Ûrünleri Sempozyumu، 391-396.
Cupp, E. E. 1977. Marine plankton diatoms of the coast of North America. Univ, Of California Press, Berkeley, p. 237.

Duzgüneş, E., M. Feyzioğlu ve M. Boran, 1995. Trabzon sahil şeridinde yer alan kafes balıkçiliği tesislerinin ekosistem üzerine olan etkilerinin araştırimasi: Kırsal Çevre ve Ormancilik Sorunları Araştırma Der: Yay, 9, 47-64.

Folke, C. and N. Kautsky, 1989. The role of ecosystems for a sustainable development of aquaculture. Ambio, 18(4), 234 243.

Gökalp, N. 1972. Edremil, Bodrum ve iskenderun körfezlerinin plankton durumunun karșlaștırmal! inceienmesi. Istanbul Univ. Fen Fak. Hidrobiyoloji Araş. Ens. Yay., 3, 71 s.

Işgören, D. 1995. Güney Ege'de çipura ve levrek işletmelerinde ekonomik optimizasyon, verimilik ve artıricı ónlemier. Doktora tezi. Ege Ûniv. Su Ürünleri Fak., Izmir, 101 s.

Koray, T., B. BÖyokıșık, H. Parlak ve \$. Gökpınar, 1992. Izmir körfezinde deniz suyu kalitesini etkileyen tek hüreli organizmalar: red-tide ve diğer așın ureme olayları. DoğaTr. J. of Biology, 16, 135-157.

Kärüm, V. 1996. Su ürànleri projelerinin verimliliği. Tarım ve Kŏy Dergisi, 112, 28-30.

Nakahara, H. 1978. Studies on phytoplankton in Maizuru Bay, Seasonal variation and vertical microdistribution. Memoirs of the College of Agriculture, 49-82.

Pankow, H. 1976. Algenflora der Ostsee II. Plankton. Gustav Fischer Verlag, Jena, p. 493.

Pillay, T. V. R. 1992. Aquaculture and the environment. Fishing News Books, Oxford, p. 189.

Pullin, R. S. V. 1993. Discussion and recommendations on aquaculture and the environment in developing countries, 312-338. In: R.S.V. Pullin, H. Rosenthal, J. L. McLean (eds.) Environment and aquaculture in developing countries. ICLARM Conf. Proc. 31, p. 359.

Sournia, A. 1986. Atlas du phytoplancton marin. Volit. Introduction, Cyanophycees, Dictyochophycees, Dinophycees et Raphidophycees. Centre National de la Recherche Scientifique, Paris, p. 219.

Stewart, J. E. 1997. Environmental impacts of aquaculture. Worid Aquaculture, March, 47.52.

Stirling, $H, P$ and $T$. Dey, 1990. Impact of intensive cage fish farming on the phytoplankton and periphyton of a Scottish freshwater loch. Hydrobiologia, 190, 193-214.

Strickland, J. D. H. and T. R. Parsons, 1972. A practical hanbook of seawater analyses. Bull. Fisheries Res. Board. of Canada, 167, p. 310.

Taylor, F, J. R. 1976. Dinoflagellates from the International Indian Ocean expedition. E. Schweizerbart'sche Verlagsbuchhandlung, Stuttgart, p. 227.

Treasurer, J, A. Grant and F. Hannah, 1999. Monitoring programmes for phytoplankton blooms. Fish Farmer, 13, September-October, 10-13. 


\title{
Seleksiyon Yapilan Japon Bıldırcını Hattında Gerçekleşen Kalıtım Derecesinin Tahmin Edilmesi ${ }^{*}$
}

\author{
M. Muhip OZKAN ${ }^{1} \quad$ Tahsin KESICl \\ Geliş Tarihi : $18,10.1999$
}

\begin{abstract}
Üzet: Bu çalışmada, japon bıldırcınlarında 7 ile 15. generasyonlar arasında 5 . hafta canli ağırlık artışı yönunde yacian seleksiyonla gerçekleşen kalıtim dereceleri $h_{1}{ }^{2}$ ve $h_{2}{ }^{2}$ olmak üzere iki yōntemle hesaplanmiş̧ıు. Gerçekleşen kalıtım derecelerl her iki yöntemde de dişilerde erkeklere oranla daha yüksek tahmin edilmiştir. $h_{j}{ }^{2}$ yöntemi ile hesaplanan kalıtım dereceieri hem dişilerde hem de erkeklerde $h_{2}^{2}$ yöntemine göre daha youksek bulunmuştur.
\end{abstract}

Anahtar Kelimeler: Japon bildırcinı, seleksiyon, kaiıtım derecesi

\section{Estimation of Realized Heritability for Selected Japanese Quail Line}

\begin{abstract}
: in this study, the heritabilities realized with the effect of selection on 5-weeks body weight of japanese quail line between $7^{\text {th }}$ and $15^{\text {th }}$ generations were calculated with two methods named $h_{1}{ }^{2}$ and $h_{2}{ }^{2}$. The estimated heritability values higher in females than in males for each methods. And also heritabilities calculated with $h_{1}{ }^{2}$ method were higher in males and females than $h_{2}^{2}$ method.
\end{abstract}

Key Words: Japsnese quail, selection, heritability

\section{Giriş}

Hayvancilikta, ekonomik değeri yüksek olan bir karakter bakımindan populasyon ortalamasının generasyonlar boyunca artırilması istenir. Bu da ancak seleksiyonla múmkündür (Düzgüneș ve ark 1996). Ekonomik aretime konu olan kultar hayvan populasyonlarinda uygulanan sun'i seleksiyon ile uzerinde durulan kantitatif bir karakteri etkileyen eklemel genlerin oran olarak miktarı çoğaltılarak, populasyon ortalamasi yükseltilebilir. Böylece, populasyonda sózkonusu özellik bakımından ekonomik değeri yüksek olan genotiplerin frekansı artırılabilir.

Lerner (1968)'e göre bir populasyonun mevcut gen kompozisyonunu muhafaza etmesi genetik homeostasis olarak ifade edilmektedir. Genetik homeostasis, populasyonun, sun'i seleksiyon baskısına karşı gen kompozisyonunu koruyan bir doğal seleksiyon etkenidir. Bu düşünce, sun'i seleksiyonla dogaal seleksiyonun ters yönde çalıştıkları varsayımından kaynaklanmaktadir. Bu varsayım, sun'i seleksiyonun populasyonda ekonomik ozellik bakimindan eklemeli etkisi yäksek genlerin nispi miktarının artmasını sağladığı, buna karşılık doğal seleksiyonun ekonomík ozellikler bakimindan orta fenotipli olan heterozigotların daha fazla dól verdiği şeklinde ifade edilebilir (Kavuncu ve Kesici 1989). Doğal seleksiyonun bu tarz işleyiși ve tek yönlú doğal seleksiyonun sun'i seleksiyona karşı etkileri deneysel olarak da araştırılmıştır (Falconer 1981)

Japon bıldircınlarında canlı ağırlık artışı ya da azalışına ait tahmin edilen kalıtım derecelerinin yumurtacı ve etci tavuklardan hesaplanan ile benzerlik göstermesi (Marks 1991), bŭyümenin genetik temelierinin araştırilmasında japon bildircinın model hayvan olarak kullaniımasını yaygınlaştırmaktadır:

Genel olarak, seleksiyonun başlangıc generasyon larında tahmin edilen kalıtım derecesi ve buna bağlı olarak da elde edilen genetik ilerleme sonraki generasyonlara oranla daha yüksektir. Nitekim 4. Hafta canlı ağırlık artışı yönünde seleksiyon yapilan grupta gerçekleşen kalitım derecelerinin $1-10$. generasyonian arasında yûksek $(0,32$ $0.45), 1-20$ generasyonlari arasinda orta $(0.22-0.32)$, 2040 generasyonları arasinda ise düşak $(0.00-0.17)$ olduğu bildirilmektedir (Collins ve ark. 1970; Marks 1991).

Dördüncü hafta canlı ağırlık artışı ve azalışı yönünde sirasiyla 0.38 ve 0.32 olarak (Nestor ve ark. 1982) tahmin edilen kalitım derecelerinin çevre şartlarına bağlı olarak farkilik gösterebileceği yani yeterli çevre koşullarinda hesaplanan canlı ağırlıga ait kalıtım derecesinin yetersiz besleme çevresinde hesaplanandan yüksek olabileceğinin bildirilmesine rağmen (Marks 1991), farklı çevre koşullarinin kalitim derecesinin hesaplanmasinda herhangi bir etkisinin bulunmadiğı da ifade edilmektedir (Tozluca 1993).

Yapilan araştirmalarda cinsiyet faktörú dikkate alındığında, gerçekleşen kalıtım derecesi 5 . Hafta canlı ağırık artışı için ilk kuşakta dișiler ve erkekler için sırasıyla 0.62 ve 0.38 (Kavuncu ve ark 1986) aynı populasyon için 1-6 kuşaklar arasında cinsiyet ayrimı yapılmaksızın yaklaşık 0.30 olarak bildirilmiştir (Kavuncu ve Kesici 1992). Yine 4. Hafta canli ağirlık artışına ait gerçekleşen kalıtım derecesi 1-6. Kuşakları arasinda dişilerde (0.58) erkeklerden (0.33) daha yüksek hesaplanmiştir (Marks ve Lepore 1968).

\footnotetext{
Ankara Universitesi, Araştırma Fonu Múdüriúgú tarafindan desteklenen 89.11.11.04 numaralı projeden özellenmiştir.

'Ankara Univ Ziraal Fak. Zootekni Bölumu-Ankara
} 
Bu çalışma ile, japon bildircınlarinda, 7 ile 15 Kuşaklar arasında 5 Hafta canli ağırlık artışı yönünden yapilacak seleksiyonla gerçekleşen kalitım derecelerinin hesaplanmasi amaçlanmiştır.

\section{Materyal ve Yöntem}

Bu çalışma Ankara Üniversitesi Ziraat Fakültesi Zootekni Bölümü Bıldırcın Yetiştiriciliği Ünitesinde değişik zamanlarda farkli alkelerden (Fransiz, Alman) temin edilen ve TÜBITAK VHAG-625 sayili projede kullanilan populasyonlarda yürütülmüștür (Kavuncu ve Kesici 1989). Alt gruplardan birisinde 5 . hafta canlt ağırlık artışı yơnünde seleksiyon yapilirken ( $C$ grubu) diğeri kontrol grubu ( $K$ grubu) olarak rastgele yetiştirilmiştir.

Bu alt gruplarda ebeveyn olarak belirlenen erkekler, her dişinin bulunduğu bólmeye dönúşumio olarak konularak, hayvanlar cinsi olgunluğa geldikten hemen sonra iki dişi bir erkeğe verilerek rastgele çiftleștirilmişlerdir. Çiftleşmenin ilk 20 gönünde hayvanlarin birbirine alışmasinı temin etmek ve dolloluk oranını artırmak amacıyla yumurta toplanmamiştir. Yumurta toplama ve kuluçkaya koyma işlemi bundan sonra oç hafta süreyle birer haftalık oç parti halinde yapilmıştır.

Civcivler çıkıștan itibaren pedigrili yetiştirmeye uygun (her ananin dölleri bir kafeste) otomatik isitmali ana makinasinda 5 hafta süreyle yüksek proteinli yavru yemiyle (\% 24.5 Protein, $3000 \mathrm{ME}$ ), 5. hafta canlı ağırlık tartıları yapıldıktan sonra da seçilen ebeveynler yetişkin bildırcınlar için hazırlanan damızlik yemiyle ( $\% 17.5$ Protein, $2750 \mathrm{ME}$ ) beslenmişlerdir.

Hayvaniar 5 haftalık iken $0.1 \mathrm{~g}$ duyarlıkı terazi ile tartıimiștır. Her grupta her kuşak elde edilen sonuçlar bilgisayara kaydedilmiștir.

Japon bildircinlarinda yumurta verimi aydinlatmaya fazlaca bağlı olduğundan, çiftleştirmelerin yapıldığı oda sürekli olarak aydınlatılmıştır.

Iki alt gruba ayrilarak olușturulan gruplarda seleksiyon yoğunluğu (entansitesi) dişilerde $\% 40$, erkeklerde \% 20 olarak planlanmıştır. Ebeveyn sayısı populasyon genişliği ve kümes imkanlarına bağli olarak bazı kuşaklarda değişkenlik göstermesine rağmen, genel olarak planlanan yapıya uygun olmuștur.

Araştırmada, C grubunda gerçekleşen kalıtım derecelerinden $\boldsymbol{h}_{\boldsymbol{f}}{ }^{2}$ her bir cinsiyet için kontrol grubuna (K grubu) göre düzeltilen seleksiyon ùstünlüğŭ $\left(d_{l}\right)$ ve genetik ilerlemelerden $\left(r_{i}\right)$ (Kojima ve Kelleher 1963; Kesici 1971), $h_{2}{ }^{2}$ ise aşağıda belirtildiği gibi hesaplanmıștir (Falconer 1981 ; Pichner 1981).

$$
\begin{aligned}
& h_{f}^{2}=b_{f}=\sum_{i} d_{i} r_{j} / \sum_{i} d_{i}^{2} \\
& d_{i}=\left(\bar{C}_{i}-\bar{C}_{i}\right)-\left(\bar{K}_{i}-\bar{K}_{i}\right) \\
& \pi=\left(\bar{C}_{i}-\bar{K}_{i}\right)-\left(\bar{C}_{i-1}-\bar{K}_{i-1}\right)
\end{aligned}
$$

Bu eșitliklerde;

d) : kuşaktaki seleksiyon ustülugăa

ri ;, kuşakta seleksiyonla sağlanan ilerleme
$\bar{C}_{,}, i$, kuşakta seleksiyon yapilan grupta seçilen ebeveynlerin ortalaması

$\bar{C}_{i} \quad \ell$ kuşakta seleksiyon yapilan grubun ortalamas!

$\bar{C}$ i-1 : i. kuşakta seleksiyon yapilan grubun bir onceki generasyondaki ortalaması

$\bar{K}_{i} ; i$ kuşaktaki kontrol grubunda rastgele seçilen ebeveynlerin ortalaması

$\bar{K}_{i} \quad:$ i. kuşakta kontrol grubunun ortalamas

$\bar{K}_{i-1}: i$ kuşakta kontrol grubunun bir onceki kuşaktaki ortalaması şeklindedir. Ayrıca,

$\boldsymbol{h}_{2}{ }^{2}$ i. kuşak ortalamasinin (kontrol grubundan sapma) eklemell seleksiyon ustüniagone olan regresyonudur.

\section{Bulgular ve Tartişma}

Beşinci hafta canlı ağırlık arţşına alt gerçekleşen kalıtım dereceleri $\left(h_{1}^{2}\right.$ ve $\left.h_{2}^{2}\right)$ dişilerde youksek $(0.05$ ve $0.09 \pm 0.02)$, erkeklerde ise dûşok $(0.03$ ve $0.06 \pm 0.02)$ olarak tahmin edilmistir (Çizelge 1).

C grubunda tahmin edilen kalitim dereceleri, bu araștırmanın yürütuldōğa generasyonlar (1-20) için bildirilen degerlerden daha çok 20 ile 40. Generasyonlar arasında belirtilen duşük sevilyell kalıtım derecelerine (Marks 1991; Marks ve Lepore 1968) benzemektedir.

Uzerinde çalışllan populasyonun ilk generasyonunda disiler ve erkekler için sirasıyla 0.62 ve 0.38 olarak bildirilen (Kavuncu ve ark. 1986) gerçekleşen kalıtım dereceleri 1-6 generasyonları arasında yaklaşık 0.30 'a (Kavuncu ve Kesici 1992), 7-15 generasyonlan arasında ise 0.03-0.069 gibi dủşük bir seviyede gerçekleşmiştir.

Bu verilerden hareketle, seleksiyon yoğunluğu ve elde edilen döl sayısının azığı sonucunda meydana gelebilecek genetik varyasyonun azalmasıyla populasyonun hizl! bir şekilde seleksiyon sinirına yani platoya (plateau) ulaşmiş olabileceği düşünulebilir. Bu daşonce literatür bildirişleri ( Collins ve ark. 1970; Marks 1991) ile uyum göstermemekle birlikte çalışan populasyonun tabiatından kaynaklanabileceği gibi, doğal seleksiyon etkenlerinden genetik homeostasisin mevcut gen kompozisyonunu muhafaza etmesi yónündeki baskısından da ilerí gelebilir.

Cizelge 1, C grubunda diși ve erkeklerde yedi lie on beșinci generasyonlar arasinda gerçekleşen kalitim dereceleri

\begin{tabular}{|c|c|c|}
\hline $\begin{array}{c}\text { Gerçekieșen } \\
\text { kalitim dereceleri }\end{array}$ & Dişi & Erkek \\
\hline$h_{1}{ }^{2}$ & 0.05 & 0.03 \\
$h_{2}{ }^{2}$ & $0.09 \pm 0.02$ & $0.06 \pm 0.02$ \\
\hline
\end{tabular}




\section{Kaynaklar}

Collings, W. M., A. Abplanalp and W. G. Hill, 1970. Mass selection for body weight in quail. Poultry Sci., 49: 926 933.

Düzgüneş, O., A. Eliçin, ve N. Akman, 1996. Hayvan Islahı, A. Ü. Ziraat Fakültesi, Ankara, Yayın No. 1437.

Falconer, D. S. 1991. Introduction to Quantitative Genetics, $2^{\text {nd }}$, ed., Longman.

Kavuncu, O., O. Düzgüneş, and T. Kesici, 1986. Correlated responce of fitness to selection for 5-week body weight in japanese quails (Coturnix coturnix japonica) I. Early Results. $3^{\text {rd }}$ World Congress Onn Genetics Applied to Livestock Production. July 16-22. Lincoln, Nebraska, U.S.A. $431-436$.

Kavuncu, O. ve T. Kesici, 1989. Japon Bıldırcınlarında (Coturnix coturnix japonica) Canlı Ağırlığa Göre Seleksiyonun Döl Verimine Etkileri. TÜBITAK VHAG-625.

Kavuncu, O. ve T. Kesici, 1992. Effect of selection for body weight on fitness in japanese quails. Doğa-Tr.J. of Veterinary and Animal Sciences. 16: 335-340.

Kesici, T. 1971. Farelerde Farklı İki Besleme Şartında Vücut Uzunluğuna Göre Yapılan Seleksiyonun illk Generasyondaki Etkileri. Doçentlik Tezi, Ankara.
Lerner, I. M. 1968. Heredity, Evolution and Society, San Fransisco: Freeman and Co.

Mark, H. L and P. D. Lepore, 1968. Growth rate inheritance in japanase quail. 2. Early Responses to Selection Under Different Nutritional Environments. Polutry Sci. 47: 15401546.

Marks, H. L. 1991. Divergent selection for growth in japanese quail under split and Complete Nutritional Environment. 4. Genetic and Correlated Responses From Generations 12 to 20 . Poultry Sci. 70 : $453-462$.

Nestor, K. E., Bacon, W. L. and Lambio, A. L. 1982. Divergent selection for body weight and yolk precursor in Coturnix coturnix japonica. 1. Selection Response. Poultry Sci. (61) $12-17$.

Pirchner, F. 1981. Population Genetics in Animal Breeding Plenium Press, New York.

Tozluca, A. 1993. Japon Bıldırcınlarında (Coturnix coturnix japonica) Farklı Besleme Şartlarında Canlı Ağırlığa Göre Yapılan Seleksiyonun Etkinliği ve Diğer Verim Özelliklerine Etkileri Üzerine Bir Araștırma. Doktora Tezi. Selçuk Üniversitesi Fen Bilimleri Enstitüsü, Konya. 